
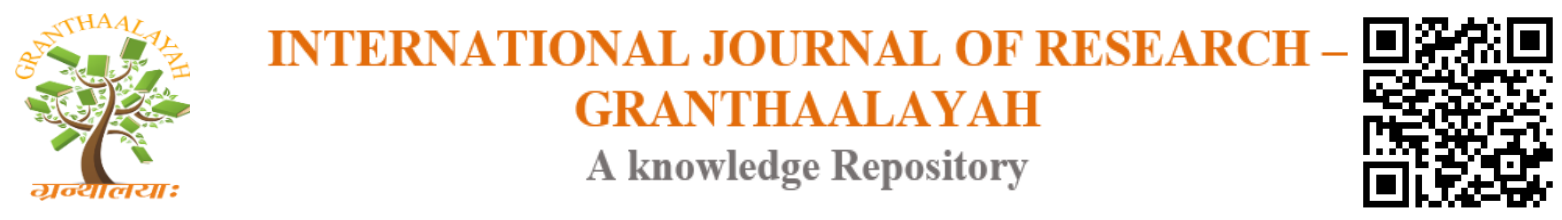

Social

\title{
HOMER'S CONCEPTION OF HONOUR AND GLORY IN THE ILIAD
}

\author{
Muhammad Ishtiaq *1 \\ ${ }^{* 1}$ Department of English, Port City International University, Bangladesh
}

\begin{abstract}
The Iliad is an ancient Greek epic poem which portrays the duration of Trojan War along with battle and events between King Agamemnon and the warrior Achilles. In this paper, the honour and glory of ancient Greek civilization has been discussed in context of The Iliad. The definitions of honour and glory has been discussed along with what motivated the ancient warriors to fight for honour and glory. This study has been carried out to find out the importance standards of honour and glory along with the importance of honour and glory in lives of Greek warriors. One of the central ideas of the Iliad is the honour that soldiers earn in combat. For an ancient Greek man, the ability to perform in battle is the single greatest source of worthiness. The glory earned by soldiers on the battlefield enabled them to live on in legend, becoming heroes who would be remembered long after death. This essence of honour and glory has been discussed in this paper. This paper has also emphasized on the heroic honour of the Greek warriors as performance of war was the simplest measurement tool to measure the heroic honour of the warriors.
\end{abstract}

Keywords: Importance of Honour; Combat; Significance of Glory; Heroisms; Ancient Tradition.

Cite This Article: Muhammad Ishtiaq. (2019). "HOMER'S CONCEPTION OF HONOUR AND GLORY IN THE ILIAD.” International Journal of Research - Granthaalayah, 7(8), 104-110. https://doi.org/10.29121/granthaalayah.v7.i8.2019.643.

\section{Introduction}

The Iliad, which is an epic poem written about the Trojan War, was the first thing written in the European tradition. Astonishingly, its quality and appeal have yet to be surpassed. This is a result of Homer's use of idealistic themes, many of which show up in many modern novels. One of the most dominant themes present in The Iliad is the pursuit of honour and glory. Even though the Achaeans and Trojans are in a violent battle with one another, both display a similar attitude: the acquisition of glory is more important than life itself. The Iliad is a poem that celebrates the heroic values war imposes on its votaries." Homer himself describes war as "bringing glory to man." War is a huge part of both the Achaeans and the Trojans' lives. Characters gain glory through their performances and bravery in battle. Furthermore, Homer persuades the reader that war is the glorious way to settle a dispute. For example, Hector and other Trojans scorn Paris for backing down from Menelaus. On the other hand, Achilles acquires glory by deferring the option of a long, 
peaceful life in order to fight and become an epic hero. The characters in The Iliad value honour and glory to such a degree that they are willing to give up life itself in order to possess it.

The Iliad which represent different culture, the western culture. Iliad this epic based on the Greek myth of "Trojan War." The details presentation of every action and scene of the epic makes these historically and culturally very important in the field of literature. There are many paperes on this epic such as religious perspective, feminist perspective and also the traditional cultural perspective but my paper discussed only about the honour and glory of the warriors.

\section{Literature Review}

Honour, a very important part of life for Greek culture, as it was valued more than life. The denial of honour was seen as the greatest of human tragedies. This was often referred to as a shame culture, where the worth of warriors was placed on their gaining reputation for heroic acts or deeds. How you were perceived, formed your identity, and essentially, formed your worth. This is where the Iliad comes in, as the denial of honour was the theme of the poem. Denial of honour is paramount when it comes to the characters of Homer's Iliad. We see examples of excess and extremes when it comes to dishonour, and subsequent punishment, for those who show said dishonour. As mentioned, the theme of the poem is based on the greatest human tragedy in Greek culture, the denial of honour. The plot and events of the play depict the extremes to which humans, and gods alike, will go to in order to attain the sought-after immortal reputation of honour.

According to William James "Representative Essays in Modern Thought," the wars in ancient Greek are purely piratical (James 02 ). He also says that pride, gold, women and slaves' excitement are their only motives. I agree with this statement, but there are also other things in it like the glory of war and the ethnic unity. When Paris elopes with Helen from Sparta and takes her back to Ilium, Menelaus appeals to his brother Agamemnon, and together they raise an expedition to bring her back. Simone Weil writes the essay entitled "The Iliad or the Poem of Force" in 1939, shortly after the commencement of World War II. The essay describes how the Iliad demonstrates the way force, exercised to the extreme in war, reduces both victim and aggressor to the level of the slave and the unthinking automaton. However, this paper only discusses about the honour and glory of Greek warriors.

\section{Materials and Methods}

The purpose of this paper is to giving emphasis on "Homer's conception of honour and glory in Homer's The Iliad. This paper is conducted basically, based on the 'Descriptive' and 'Analytical' approach in nature and based on Secondary sources. In this paper analogy of most of the writers as well as learners and scholars have been critically evaluated and analyzed, and some information or materials related to this paper from the sources several journals, websites, articles as well as text books to make them successful and authentic. 


\section{Discussion}

\section{Significance of Honour and Glory}

Honour and Glory was an inseparable aspect of great ancient Greek civilization. Gaining honour and glory is not always simple, as there are different and often conflicting ways of achieving status and respect. One of the more obvious methods depicted in the Iliad is success in battle, as well as courage. Achilles and Hektor are noted as great fighters, and both of them greatly affect a battle with their presence. Achilles' decision to abstain from the fighting because he was slighted by Agamemnon carried enough weight to force consideration of defeat. "Glorious" Hektor, "who was ever the bravest fighter of the Trojans (Homer, Iliad 6.460)", also demonstrates extreme courage and battle prowess by continually expressing a desire to return to battle while his duties force him on errands into the city (Homer, Iliad Book 6). His brother Paris, on the other hand, the instigator of the war, must be dragged out of the city to fight, causing other Trojans to say "shameful things (Homer, Iliad 6.524)" about his character. Similarly, success in athletic competitions also leads to honour and glory. In a nutshell, The Greeks placed great importance on personal honour. Why is this? Is it because to them man I nothing without honour. Or is it that the honour is more important than the man? "Honour to the Greeks is something that is won by a man's prowess, his ability to fight and be victorious on the battle field"(Schein 62). This is just one example of how honour is obtained. A second method of gaining honour is to be a great orator, one must possess the ability to speak in the assembly and express his ideas eloquently, and persuasively to the gathered body. A third way of achieving personal honour is to demonstrate athletic ability.

\section{Effects of Honour and Glory in the Iliad}

Honour and glory are central to the Greek character. Since heroes are the essence of the society from which they come, Greek heroes live their lives according to honour and glory, in all their varied forms. Honour and glory trigger an epic war that takes the lives of numerous men, and shape its development at every stage. The fall of Troy is "a thing... whose glory shall perish never (Homer, Iliad 2.324)". The goal of the Greeks is the fame that resounds even after death, and they let nothing bar their way. The honour of the individual, family, and community guide every action and response. Honour and glory define the hero, and therefore are the foundations for everything that comes to pass in Homer's Iliad. The concepts of honour and glory are critical to understanding the motivation of the heroes in Homer's Iliad. Glory was gained by great, heroic actions and deeds and was conferred upon an individual by others who witnessed and acclaimed the glorious actions. Major battles provided an opportunity for many to find glory at once. Honour was similar to glory, but while the public had to view actions and deem them glorious, each individual maintained their own sense of personal honour which did not always coincide with honour as defined or perceived by the masses. Honour was gained through heroism in battle, but also through compelling speechmaking, loyalty and other noble qualities that a person might demonstrate. Having honour and glory allowed a Greek to gain influence in their society; as Osborne writes, "Individuals exert political influence according to their social standing, their rhetorical abilities, and their personal charisma, but not according to their holding the office of ruler (Osborne, 150). An example that demonstrates this point occurs in the Iliad amidst an argument over a possible retreat. Odysseus, a respected fighter, makes the claim that it is "disgraceful to wait long and at the end go home emptyhanded (Homer, Iliad 2.297)". His message is well received. Meanwhile, Thersites, a man- and commoner- despised by all, advises the army to return home and is struck down by Odysseus to the pleasure of the gathered crowd. Here the respect and honour that Odysseus has achieved lends 
sufficient weight to his argument that his opponent, without equivalent status, is barely allowed to retort. The honour and glory an individual has gained increase the respect and influence he commands as well.

Honour and glory were important to the ancient Greeks because social status was not fixed. Indeed, in the eyes of the Greeks "social status correlates closely with access to power, but does not fully determine it (Osborne, 155)." Positions of power were not simply inherited, and through honourable and respected actions a person could elevate their social position significantly. This mobility in Greek culture inspires a cooperative attitude between the local leaders and the people following them. The leaders require the voluntary cooperation of the people under them, and only achieve that with respect and honour. This quality allows Achilles to disobey Agamemnon and refuse to fight when Agamemnon dishonours him by taking his prize. Many of the strategic decisions for the army that are made throughout the Iliad are reviewed by a group of respected fighters and elders, even though Agamemnon is considered the main leader. In book nine, facing a rout at the hands of the Trojans, Agamemnon calls a counsel of leaders to persuade them that the army should "run away with our ships (Homer, Iliad 9.27)" before losing more men. However, Agamemnon's suggestion shocks his audience, and his idea is emphatically rejected. Diomedes states, "if in truth your own heart is so set upon going, go... yet the rest of the flowing-heart Achaians will stay here until we have sacked the city of Troy (Homer, Iliad 9.42)". Agamemnon's leadership position can easily be transferred to another, if he begins to falter. Status could always be gained and lost, and therefore it was necessary to continually protect your honour and resulting status while striving for more.

\section{Parks of Heroic Honour}

According to the Iliad, there are some parks of Heroic honour. The goal of Homeric heroes is to achieve honour. Honour is essential if one wants to be a hero. Some of the parks are pointed below: (i)Heroes value honour above life. Hector contemplates his options but determines that he has no choice to maintain his honour and gain the respect of Achilles, he must fight and leave his fate in the hands of the gods. (ii)Heroes must have the ability to spellbound the audience with charming and soothing speech. (iii)Honour is gained through engagement in life-threatening activities (a hero cannot avoid threatening situations and maintain his honour). Other characters often advise heroes to stay away from certain situations (Achilles warns Patroclus not to attack Troy; Polydamas tells Hector to lead the Trojans back to the city and fight with them there; Priam and Hecuba beg Hector not to fight Achilles), but to be heroic, heroes must ignore the advice. (iv)Honour is determined by a number of things: the courage he displays, the difficulty of the test he faces the physical abilities he possesses, his social status, and the possessions that he acquires, i.e., the spoils of his victories and other athletic ability.

\section{What defines Honour and Glory in Iliad}

Possession of women was important to a man's standing and honour. Paris' theft of Helen struck a huge blow to the honour of Menelaus and became the initial cause of the war between the Greeks and the Trojans. The Spartan ruler called upon his brother Agamemnon to gather the Greek forces to forcefully persuade Paris to return Helen and reinstate respect for the king. In this case, others sympathize with the blow to Menelaus' honour, and Achilles and other famous Greek leaders agree to join the fight to recapture Helen and the honour of Menelaus. The theft of Menelaus' woman 
justifies the initiation of the war, and the later theft of Achilles' woman intensifies the war with his absence.

The Greeks had subtler distinctions of status in addition to these physical, and personal, demonstrations of honour. Homeric society was very community-based, as can be seen with the collective nature of the ruling class. This communal sentiment often conflicts with individual desires. Many times, throughout the Iliad what is best for the group is rejected for individual honour. Menelaus and his brother Agamemnon wage war to regain honour, despite the cost of the lives that will be lost in the process. There are multiple instances throughout the Iliad where the question of standing down to prevent others from being killed is rejected as cowardly or weak, and the fight continues.

With the massive struggle between two of the Greeks' greatest men, Agamemnon and Achilles, to retain their honour in the public view, it becomes clear that there are different views on honour within the society. Agamemnon felt his personal honour was greater than that of the army, but Achilles calls him out as "wrapped in shamelessness, with your mind forever on profit (Homer, Iliad 1.149)". Both of the heroes see their women as a sign of status and honour, but relinquishing the symbol of honour for the sake of the army, as in Agamemnon's case, does not necessarily diminish his personal honour. Many other respected men, such as Odysseus, try to convince Agamemnon to calmly return his prize, but Agamemnon is overwhelmed with the idea that he is being slighted. In this situation, the communal sentiment outweighs that of the individual. To save lives, Agamemnon must give up a possession, which is not viewed by the community as dishonourable. However, Agamemnon's perceived slight does not compare with the insult to Achilles' honour with Agamemnon's appropriation of his woman. Achilles feels his honour as acutely as Agamemnon, and declares, "I am minded no longer to stay here dishonoured and pile up your wealth and luxury (Homer, Iliad 1.170)," as he removes himself from the main camp. Achilles gives up the prospect of gaining certain glory on the battlefield, and having "the Achaians [honour] you as they would an immortal (Homer, Iliad 9.603)", to preserve his honour off the field. The idea of family honour adds a new level of intricacy in maintaining a balance between individual and community honour. For the Greeks, family honour is similar to community honour. Menelaus calls upon his brother when his honour is wounded with the theft of Helen. Agamemnon responds to the familial need, and the community does as well, providing more support for Menelaus' difficult situation.

Individuals of a family, like those of a community, do not always have the same ideas on what constitutes the proper actions to take in a given situation. Patroclus is like family to Achilles, as they grew up together, practically brothers. Patroclus respects Achilles' decision to remain out of the fighting, but also desires to achieve his own honour by inspiring fear into the Trojans by wearing Achilles' armor, since Achilles himself will not. His honour is shown in the elaborate ceremonies that Achilles holds for his passing, and the extent of the mourning shown.

\section{Importance of Honour and Glory in Greek Civilization}

Honour and glory were at the core of Greek civilization in Homer's time, as the Greeks recognized that honour and glory last far longer than any physical remnants of a person's life. The pursuit and protection of these qualities in all their various forms were the driving force behind everything the Greeks did. Honour and glory made it reasonable to go to war, to fight with friends, to lose 
countless comrades and to be away from home and family for decades. In the Iliad, honour and glory were life.

In the beginning of Homer's, The Iliad, the very first collection of lines talks of honour and glory, stating that the fall of Troy is "a thing... whose glory shall perish never." You can clearly see that glory and honour were a central part of the Trojan War. In one shining example, you can see that honour affords characters' privileges that those without cannot have: Odysseus, a highly respected fighter, rallies the troops and boosts their spirits before they decide to retreat. Odysseus makes the claim that it is "disgraceful to wait long and at the end go home empty-handed." The troops are again in good spirits and ready to carry on battling. When one among them named Thersites, a commoner who is disliked by many, speaks up and advises the men to retreat, Odysseus strikes him down. The crowd revels in Thersites' defeat. The man with honour is able to silence the one without. This act shows how brandishing one's pride and honour defines one's worth.

Honour and Glory was the only way of living for ancient Greeks as a man without honour and glory is considered as naught in ancient Greek civilization.

\section{Conclusion}

The theme of the Iliad is Honour and Glory over anything else. After studying the Iliad, it is understood that to fight is to prove one's honour and integrity, while to avoid warfare is to demonstrate laziness, ignoble fear, or misaligned priorities. The characters of the Iliad often make reference to the great heroes of past ages, such as Hercules and Theseus. For the ancient Greeks, the term "hero" meant something stricter than it does today: the hero's military glory could make him nearly as important as a god. Honour was supremely important to the ancient Greeks and underlies nearly every interaction in the poem. Honour can be gained through position, athletics, or debate; and particularly in wartime, it is built by demonstrating skill and bravery in battle and seizing valuable prizes. Fighters make themselves vulnerable in battle by stripping their defeated enemies of their armor as battle trophies. They even wear it to emphasize their triumph. Conversely, fierce battles are fought to keep enemies from gaining the honour of looting comrades' bodies. Leaders such as Agamemnon inherently have more honour, but they assume the dishonour for their followers in the case of defeat. The choices of both Hector and Achilles demonstrate that honour and glory are more important than long life. This paper has identified and discussed the various aspects of Honour and Glory in the Iliad.

\section{References}

[1] Homer. The Iliad. Tr. by Robert Fagles. New York: Penguin, 1990.

[2] Knox, Bernard. Introduction to The Iliad. Tr. by Robert Fagles. New York: Penguin, 1990.

[3] Homer. The Iliad of Homer. Tr. by Richard Lattimore. Chicago: U. of Chicago Press, 1951.

[4] Lattimore, Richard. Introduction to The Iliad of Homer. Chicago: U. of Chicago Press, 1951.

[5] Campbell, Joseph. The Masks of God: Occidental Mythology. NY: Penguin Books, 1964.

[6] Delahoyde, Michael. Medieval Dragons and Dinosaur Films: Popular Culture Review 9.1 (February 1998): 17-30.

[7] Genesis. In The Norton Anthology of World Masterpieces, Vol. I. NY: W.W. Norton and Co.1985.

[8] Grant, Michael. Myths of the Greeks and Romans. NY: Penguin Books, 1962.

[9] Homer. The Iliad. Trans. Robert Fagles. NY: Penguin Books, 1990. 
[10] Hughes, Collin. Mythopoeia. http://www.wsu.edu/ hughesc (12 Sept. 2000).

[11] Momaday, N. Scott. The Way to Rainy Mountain. University of New Mexico Press, 1969.

[12] Morford, Mark P.O., and Robert J. Lenardon. Classical Mythology. 4th ed. NY: Longman, 1991.

[13] Ovid. Metamorphoses. Trans. Rolfe Humphries. Bloomington: Indiana University Press, 1961.

[14] Pomeroy, Sarah B. Goddesses, Whores, Wives, and Slaves: Women in Classical Antiquity. NY: Schocken Books, 1995.

[15] Powell, Barry B. Classical Myth. http://www.prenhall.com/powell (3 Oct. 2000).

[16] Sappho. "To Aphrodite." In Women's Life in Greece and Rome: A Source Book in Translation. Ed. Mary R. Lefkowitz and Maureen B. Fant. Baltimore: The Johns Hopkins University Press, 1992. 2.

\footnotetext{
*Corresponding author.

E-mail address: ishtiaq.reza91@ gmail.com
} 